\title{
TRUTH-TELLING BY WRONG-DOERS? THE CONSTRUCTION OF AVOWAL IN CANADA'S TRUTH AND RECONCILIATION COMMISSION
}

\section{Jason Chalmers \\ University of Alberta}

The truth commission has emerged in the last thirty years as a distinct juridical form that views the production of truth as necessary, and in some cases sufficient, for achieving justice. In his history of truth-telling in juridical forms, Michel Foucault conducts a genealogy of avowal (or confession) in western judicial practice; critical to his definition of avowal is that the truth-teller and wrong-doer must be the same individual. In my analysis, I consider avowal in light of a relatively recent judicial innovation: the truth commission. This is carried out through use of Canada's Indian Residential Schools Truth and Reconciliation Commission (TRC) as a particular case study. The TRC's emphasis on the testimony of victims rather than perpetrators means that truth-telling and wrong-doing are decoupled in this juridical form, suggesting that avowal is not a function of truth commissions according to Foucault's criteria. Does this mean that truth commissions are not involved in truth production? Or perhaps that they are not a juridical form in the lineage of those examined by Foucault? The truth commission is a juridical form that Foucault was unable to address because it developed after his death. It is possible that the truth commission challenges his core understanding of avowal; however, the truth commission also appears to be consistent with trends that he predicted about the role of truth-telling in the modern judicial system.

Keywords: truth commission; transnational justice; residential schools; avowal/confession.

La commission de la vérité est apparue dans les trente dernières années sous une forme juridique distincte qui voit la production de la vérité comme nécessaire et dans certains cas suffisante pour rendre justice. Dans son histoire sur la vérité et les formes juridiques, Michel Foucault mène une généalogie d'aveux (ou de confessions) dans la pratique juridique occidentale. Ce qui est critique à sa définition d'aveu est que la personne qui dit la vérité et qui agit mal doit être la même. Dans mon analyse, je considère l'aveu à la lumière d'une innovation juridique relativement récente : la commission de la vérité. Ceci est effectué comme étude de cas particulier pour la Commission de la vérité et de la réconciliation relatives aux pensionnats indiens du gouvernement du Canada (CVR). La CVR met l'accent sur le témoignage des victimes et non sur celui des auteurs ce qui signifie que la personne qui dit la vérité et celle qui agit mal sont dissociés dans cette forme juridique, suggérant que l'aveu n'est pas une fonction de la commission de la vérité selon les critères de Foucault. Cela signifie-t-il que les commissions ne sont pas engagées envers la production de la vérité? Ou, peut-être qu'elles ne sont pas une forme juridique dans la même lignée que celles étudiées par Foucault? La commission de la vérité est une forme juridique que Foucault n'a pas été capable de traiter car elle s'est développée après son décès. Il est possible que la commission de la vérité dévie de sa compréhension de base de l'aveu, cependant, la commission de la vérité semble également être cohérente avec les tendances prédites au sujet du rôle de la production de la vérité dans le système juridique moderne.

Mots-clés: commission de la vérité; justice transitionnelle; pensionnats; aveu/confession. 
The truth commission has emerged in the last thirty years as a distinct juridical form that sees the production of truth as necessary, and in some cases sufficient, for achieving justice. Although some scholars address the relationship between truth and reconciliation, focusing on whether it is possible to achieve reconciliation via truth (Bachmann, 2010; Clark, 2012; Corntassel and Holder, 2008; Twose, 2010), a more fundamental question is what truth commissions mean when they refer to 'truth.' Given the contested territory that 'truth' has become in the postmodern era, it is unsurprising that truth commissions define it in different ways, with some actively acknowledging truth as a multiplicity by identifying and documenting several different kinds (Kashyap, 2009; May, 2013; Roosa, 2008). Yet it is difficult to define truth without also considering who has defined it and to whom it belongs. Scholars criticize truth commissions on the grounds that they reproduce existing power relations while doing little to undermine them, the effect of which is that the truth being told is ultimately that of the oppressive state or class (Corntassel and Holder, 2008, French, 2009; Garman, 2006; Macias, 2013); while still critical of truth commissions, others acknowledge that they can convey the truth of victims in ways that reverse oppressive power dynamics (James, 2012). The idea that truth commissions somehow establish truth is an often unquestioned assumption, and it may in fact be the case that there is no correspondence between truth commissions and truth production. McCalpin (2013) suggests that truth commissions do not necessarily produce truth and that some do indeed fail at this ostensibly basic task, and Jeganathan (2010) contends that their dependence on victim testimony means that some commissions ultimately render the inadequate 'ruins of truth.'

I take these concerns as a starting point for the present discussion by asking how truth is defined in truth commissions and ultimately raising the question of whether truth is produced through their proceedings. To do this, I rely on Michel Foucault's Wrong-Doing, Truth-Telling: The Function of Avowal in Justice, a series of lectures delivered in 1981 - although not fully published in English translation until 2014. In these lectures Foucault conducts a genealogy of avowal as truth-telling in western juridical practice. For Foucault, truth is a product of the power dynamics of the institutions that constitute society; truth is bound to social structures and therefore constructed within a particular socio-historical context. Truth-telling (or veridiction, which includes avowal or confession) is a verbal enunciation in which a subject acknowledges a particular truth as authoritative and thereby recognizes the authority and legitimacy of those social institutions that produce it (Foucault, 2014, p. 19-21). I begin by dissecting Foucault's definition of avowal to determine the parties necessary for avowal and how each is positioned in relation to the act. I demonstrate that, if avowal is to occur and not some other form of veridiction, it is imperative that the truth-teller and wrong-doer be the same subject. I then consider how this corresponds to the form of veridiction produced by the Indian Residential Schools Truth and Reconciliation Commission (TRC) in Canada. A close reading of the TRC mandate reveals that truth-telling and wrong-doing have been decoupled and are consequently enacted by different parties. Does this mean that truth commissions are not juridical forms that operate by means of avowal? By situating truth commissions in Foucault's genealogy of avowal I hope to demonstrate that they fit genealogically into the history of western justice systems and that, rather than reflecting a theoretical need to separate avowal from truth commission, ostensible contradictions point towards recent shifts in the justice system of which Foucault seems to have foreseen.

Foucault's definition of 'avowal' warrants close attention due to the surprising precision with which it is crafted; here, avowal is framed as a reflexive act. Foucault's genealogical research addresses various practices - knowledge, discipline, sexuality, among others - as social constructions that are constituted within a particular historical context. Because each practice exists 
within a specific place and time, its uses and meanings will vary so greatly that it is nearly impossible to provide a precise and unchanging definition. Accordingly, when Foucault goes to lengths to establish a clearly articulated definition of a practice such as avowal, this definition presumably carries much gravity and warrants close inspection. In Wrong-Doing, Truth-Telling, Foucault offers what seems to be a clear, integrated, and painstakingly worded definition of 'avowal.' In his succinct definition, Foucault (2014) states:

...That avowal is a verbal act through which the subject affirms who he is, binds himself to this truth, places himself in a relationship of dependence with regard to another, and modifies at the same time his relationship to himself. (p. 17)

This definition frames avowal as a reflexive act through which one acts upon oneself: through the act of avowal one affirms himself, binds himself, places himself, and modifies himself. (I retain Foucault's use of gendered language not just for consistency, but because I suspect it expresses something important about the gendered nature of truth and justice). Although avowal may change one's relationship to others, this is not because they have acted upon others, rather it is the effect of changing the subject's relationship to himself. And although the subject can coherently and meaningfully say 'I avow,' this does not mean that avowal occurs in an intransitive sense; to avow is a reflexive verb so that when one says 'I avow' what is meant is 'I avow myself.' For Foucault, avowal cannot be directed towards others nor can it be received from them, as it is defined exclusively as a process through which the subject acts upon himself.

In an expanded definition, Foucault identifies and develops four distinct characteristics of avowal. First, avowal "runs the risk of being costly" and comes at a price to the subject who avows (Foucault, 2014, p.16). The untold thing that the subject avows holds "a great value" for the avower so that, by making it told, they risk losing something important (Foucault, 2014, p.15). The subject cannot avow if he does not pay a certain price for it, and although it is not certain whether he will actually pay the full sum, it is the risk of payment that makes avowal such a serious act. Second, avowal must be voluntary because it is a statement about the avowing subject. Through the act of avowal, the avower "promises to be what he affirms himself to be" (Foucault, 2014, p. 16). Precisely because it affirms something about the subject it must originate with him; avowal that is coerced and therefore not "necessarily free" does not truly originate with the speaker (Foucault, 2014, p. 16). Third, avowal takes place within the context of a power relation. Because avowal requires both an avower as well as a party to acknowledge the avowal, the avower effectively "submits" to the other party and articulates his obedience to the other. Avowal therefore produces or maintains "a power relation that exerts itself on the one who avows." Avowals are 'costly' for this reason: they require one's submission to another (Foucault, 2014, p. 16-17). Fourth, avowal "ties the subject to what he affirms" and modifies the relationship between the avower and the thing they avow. To avow is to identify with the thing that the subject avows, yet the act of identification "will modify the relationship between the [avower] and his [wrong-doing]"; the avower becomes the act, and in doing so changes their relation to the self as well as that act. This might be perceived as a reversal of fortune or a shift in the trajectory of the subject's healing process (Foucault, 2014, p. 17). Foucault (2014) uses Greek tragedy as an example to demonstrate how an act of veridiction reveals "the real identity of some hitherto unknown or misknown person" which consequently "reverses the good fortune of the characters and transforms happiness into misery or luck into misfortune" (p. 62). 
According to this definition, avowal can only occur if it disadvantages the avower in some way. The first characteristic of avowal is that the avower must experience it as a loss or potential loss; they must pay, concede, or relinquish something they value. The third and fourth characteristics explain that this is because the act of avowal changes the subject's relation to oneself as well as to others, and that this change does not benefit the avowing subject. The avower becomes something different than the person they used to be, and this new identity does not necessarily place them in the sort of privileged position that they may have previously occupied. In fact, it is almost certain to place the subject in a subordinate position because it requires them to submit to the will of another. For the avowing subject, avowal is always a process through which they lose privilege and become disadvantaged, and this precludes the possibility of avowal occurring in contexts where a speaker stands to benefit from the act of veridiction. The subject can enact veridiction that is voluntary and modifies his relationship to himself and others, but if the subject stands to gain from the act-by gaining a dominant position, for example - it cannot be considered avowal. The preposition 'of dependence' in Foucault's (2014) concise definition is therefore crucial because it signifies that veridiction can have a dramatic effect on the subject's fortune but, unless that effect is for the worse, veridiction is not avowal.

Avowal is characterized by a downward turn in the subject's affairs and this is rooted in the notion that avowal acknowledges an act of wrong-doing. The particular acts that are defined as 'wrong' will vary between contexts. The reason for this variation is that 'wrong' is always defined by and within the context of a particular community. In his core examples of Greek literature and Christianity Foucault (2014) shows how 'wrong' has varying definitions within diverse communities. In the literature of Homer and Sophocles, 'wrong' is defined by a community of gods but must be recognized by mortal humans. In fourth and fifth century Christianity, 'wrong' is defined by the subject's religious community and this leads to the strength of an individual's connection to a monastic community depending upon whether or not they have committed a wrong. When a subject commits an act defined as wrong, he effectively undermines the integrity of that community and consequently places himself in a subordinate position to that community. Subordination is therefore a condition that emerges from the act of wrong-doing, while avowal is what acknowledges the wrong-doing and the subject's wilful submission to the community; avowal does not create a subordinate position, but simply recognizes it. Foucault (2014) articulates the communal origins of 'wrong,' and the relationship between wrong-doing and the subject's recognition of wrong-doing, in the sixth Louvain lecture:

So what serves as the foundation of the law is the will of all. And, as a consequence, one of the most frequent and most essential themes in the penal theory of the eighteenth century, but also in contemporary penal theory, is the principle that when someone has committed a crime, he himself punishes himself - through the law to which he is supposed to have consented or that he is supposed to support of his own free will...Why, at bottom, is the avowal there? Not only so that the individual might say, 'Well yes, I committed such and such a crime,' but so that in saying this, he manifests in a way the very principle of the penal law; he takes on the role of the guilty party and recognizes through his avowal the sovereignty both of the law and the tribunal that will punish him and in which he recognizes himself. (p. 207) 
If wrong-doing is subject to some kind of penalty issued on behalf of the community or individual who has been wronged - a fine, imprisonment, exile, among others - avowal is confirmation that the subject is willing to pay the price. Avowal therefore requires someone who has transgressed, deviated, or committed a crime, and it is only this type of subject who may avow. Foucault (2014) demonstrates how Oedipus was punished (or rather punished himself) through blindness and exile for the transgressions of murder and incest, and also points to how a fourth century Christian monastic was punished through exile for the transgression of sin. To summarize, avowal can only be enacted by one who has transgressed; avowal can only occur when wrong-doing and truth-telling are united in a single party.

The dual requirement of transgression and reflexivity is articulated in Foucault's (2014) treatment of the modern judicial process that was institutionalized during the medieval period and persisted into the twentieth century (and now twenty-first century, though Foucault did not live long enough to make that analysis) (p. 201-210). This judicial process requires three parties: a victim who has been wronged, an accused who purportedly committed the wrong-doing, and a judge who evaluates the veracity of those claims made by the two other parties. Through the application of various techniques for truth production, the judicial procedure aims to have the judge produce truth based on the examination of the relevant parties. Although avowal from the accused was initially only able to produce a partial truth, by the nineteenth century avowal from the wrongdoer alone was sufficient to produce truth. For Foucault (2014), "avowal by the guilty party has become a fundamental need of the [judicial] system...because the very foundations of the system were put on the table in the case of avowal, and they called for avowal" (p. 209). Avowal is essential in modern judicial procedure and institutions because the entire framework of this system is built upon the act, although it is not just any avowal that is needed but avowal from the accused party. If the accused avows - avowing the crime they committed and the criminal that they are - the judge can be certain that the avowing subject recognizes the truth.

Since Foucault's death, the truth commission has emerged as a juridical form that functions at the national level but is present on the global scale - a juridical form that I propose complicates Foucault's (2014) understanding of veridiction and avowal. Broadly speaking, truth commissions are an approach to transitional justice that tend to be (though not always) established during shifts in state structure from an oppressive or authoritarian regime to a liberal or democratic one. Truth commissions work to address state crimes against state subjects through the involvement of a series of judicial proceedings, institutional reforms, and reparative programs (Hayner, 2011). The explicit purpose of a truth commission is to achieve reconciliation and justice by breaking "the silence about widely known but unspoken truths" of state crimes (Hayner, 2011, p. 20). This is consistent with Foucault's (2014) description of avowal as the "passing from the untold to the told" (p. 15). Proceeding from a series of court cases against the Canadian government by the former students of Indian Residential Schools (IRS), Canada established the Indian Residential Schools Truth and Reconciliation Commission (TRC) in 2008, which concluded its hearings in 2014. In the following section, I use truth commissions as a means to illustrate Foucault's (2014) definition of avowal and use the definition to consider the relationship between avowal and the truth and reconciliation process. I take the TRC mandate as the particular discourse with which to conduct my analysis because the mandate for a truth commission "define[s] the truth that will be documented" (Hayner, 2011, p. 75). But before addressing how this mandate defines the actors necessary for the truthtelling process, I first consider power relations in a settler society such as Canada.

Although academics accept that power relations in settler societies cannot be reduced to simple patterns of settler versus native, there is nevertheless a heuristic tendency to classify settler 
societies in terms of binary relations. In particular, two dominant binary constructions are relevant to the current analysis: the settler/native pair and the perpetrator/victim pair. The settler/native binary views the settler state as occupied by two distinct socio-cultural groups: the settler class whose ancestors, usually of European origin, migrated to, settled, and colonized the territory during a period of recorded history, and the Indigenous residents of that territory whose ancestors have existed there since prehistoric times. Scholars criticize such frameworks as an extreme oversimplification, noting for example that most territories have experienced multiple waves of migration during both prehistoric and historic times. Additionally, many 'settlers' come from families who have lived in a territory for generations, and neither group can be viewed as ethnically or culturally homogenous. Nevertheless, scholars suggest that, because settler societies are widely perceived in popular thought as being characterised by a settler/native binary, the distinction is still a methodologically and theoretically useful one to make (See Stasiulis and Jhappan, 1995; Mbembe, 2001).

The settler/native binary articulates the origin narrative of a settler state, and when paired with a perpetrator/victim binary it exposes a distinct power relation. The perpetrator/victim construction conceives of the perpetrators as an oppressive group that imposes culture on the natives through the process of colonization, with the victims being conceived of as an oppressed group who are socially, culturally, and physically controlled by colonial institutions. This binary is likewise deconstructed by scholars based on the notion that neither group is fully powerful or powerless; members of the oppressive class are oppressed themselves and that oppression is intersectional and stratified. When the two binary patterns are combined it becomes clear that there is a distinct power relation characterizing settler societies: the settlers are the oppressive perpetrators of colonialism and the natives are the oppressed victims. While some theorists accept the settler-perpetrator/native-victim binary as overly simplistic, this model is often used as a heuristic starting point for analysis of power relations in colonial contexts, and this binary continues to regenerate in academic and popular thought (See Stasiulis and Yuval-Davis, 1995).

Power relations in Canadian society, particularly as they relate to the colonial institutions such as IRS and the TRC, are often viewed in terms of a settler/native binary. In Unsettling the Settler Within, Regan (2010), a self-identified "non-Indigenous woman [and] colonizerperpetrator," develops a pedagogical framework for the decolonization of Canadian history (p. 24). Through examination of the dynamics of IRS and TRC, Regan (2010):

Argue[s] for a truth-telling dialogue that begins with deconstructing our identity and our myths about the history of Indigenous-settler relations. Within the IRS discourse in Canada, the binary oppositions of colonizer/colonized, oppressor/oppressed, and perpetrator/victim have been reinforced in counterproductive ways. (p. 66)

Regan (2010) recognizes that these binaries are not helpful in the truth-telling and reconciliation process and her ultimate goal is to deconstruct and replace them with a model that is less antagonistic. However, Regan (2010) also recognises that this deconstructed framework is idealistic and does not reflect the contemporary situation as oppositional binaries continue to plague colonial thought. The dominant way of thinking about power relations in Canada views society as composed of oppressive settlers and oppressed natives, and this view is reinforced in practice. 
In its official mandate, the TRC attempts to deconstruct simplistic understandings of settler societies but ultimately lapses into the settler/native binary. From the outset, the mandate emphasises the complex and nuanced relations of Canadian society by explaining that:

Reconciliation is an ongoing individual and collective process, and will require commitment from all those affected including First Nations, Inuit and Métis former Indian Residential School (IRS) students, their families, communities, religious entities, former school employees, government and the people of Canada. Reconciliation may occur between any of the above groups. (Indian Residential Schools Settlement Agreement [IRSSA], 2006, Principles section).

The history and legacy of IRS cannot be understood in terms of a simple settler/native relationship because each aspect of the binary is composed of many distinct groups and subgroups. Every group has been impacted by residential schools in its own way, so it is possible - and even necessary for the reconciliation process - for each group to engage with multiple others. However, the mandate quickly slips from a nuanced understanding of reconciliation to a simplified framework. Rather than addressing the distinct experiences of the multiple groups involved in the reconciliation process, the mandate emphasises "the unique experiences of First Nations, Inuit, and Métis former IRS students" (IRSSA, 2006, 4. Exercise of Duties section (a)). Indigenous groups are lumped together and imputed with the same 'unique experience' that not only fails to address distinctions between these groups, but also ignores the ways that others, particularly non-Indigenous groups, have been impacted by IRS. Ultimately, the TRC resorts to traditional patterns by depending on a distinction "between Aboriginal and non-Aboriginal Canadians." (IRSSA, 2006, Principles section)

Consistent with binary perceptions of power relations in settler societies, the TRC mandate constructs Indigenous subjects as the victims of the IRS system. A key principle of the TRC is that it takes a 'victim-centred' approach to the truth and reconciliation process which should, if one believes the mandate principles, include nearly every individual and group in Canadian society in one way or another. However, the mandate continues to "recognize that ownership over IRS experiences rests with those affected by the Indian Residential School legacy," suggesting that particular groups have been impacted while other have not (IRSSA, 2006, 10. Events section (A)(i)). By acknowledging "the injustices and harms experienced by Aboriginal people and the need for continued healing" the mandate suggests that it is largely Indigenous people who are impacted by IRS (IRSSA, 2006, 10. Events section (A)(i), emphasis removed). Despite that the mandate attempts to deconstruct binary patterns related to the legacy of IRS, it reduces Indigenous people to a homogenous mass and constructs them as the primary victims of Canada's colonial legacy.

Although the TRC retroactively acknowledges IRS as a crime and creates Indigenousvictims as the object of that crime, it is prevented from defining the perpetrators. The mandate clearly indicates that the commission is prohibited from the accusation and judgement of perpetrators and that the commissioners must conduct proceedings:

Without making any findings or expressing any conclusion or recommendation, regarding the misconduct of any person, unless such findings or information has already been established through legal proceedings, by admission, or by public disclosure by the individual. Further, the Commission shall not make any 
reference in any of its activities or in its report or recommendations to the possible civil or criminal liability of any person or organization, unless such findings or information about the individual or institution has already been established

through legal proceedings. (IRSSA, 2006, 2. Establishment, Powers, Duties and Procedures of the Commission section (f)).

In other words, the TRC cannot create criminal subjects. This is significant given that Foucault (2014) suggests "by introducing the avowing subject, it was no doubt believed that it could bring about the fortunate coincidence between the author of the crime and the subject who had to account for it" (p. 200). It is within the criminal that subjectivity, wrong-doing, and avowal are unified. Although the mandate explicitly prevents the TRC from identifying the criminal(s) responsible for the crime of IRS, the binary logic of the mandate directs the interpreter towards the culpable party; by reinforcing the native/settler binary and constructing the native as a victim, the implication is that Canada's settler community constitute the perpetrators. On a political level, prohibiting accusation obviously prevents the TRC from attributing guilt to government institutions and officials that might later have implications in federal or international courts. On the judicial level, this means that there is no accused party to be interrogated, judged, or to avow to the crime. The TRC does not deny the existence of a criminal, but is prevented from creating a criminal subject who can identify himself and speak his own truth.

In the absence of an avowing subject, the task of veridiction is left to the Indigenous-victim. One of the primary activities of the TRC is 'statement taking/truth sharing' whereby the commission "receive[s] statements and documents from former students, their families, community and all other interested participants" (2006, Terms of Reference 2a). Through this documentation, the TRC "creat[es] a record or statement of...truths, insights and recommendations" which it then institutionalizes via "historical research and report[s], national events, and...the research centre" (IRSSA, 2006, 10. Events section (B)(d)). In short, the 'statement taking/truth sharing' process allows the Indigenous community to provide testimonies about the impact of residential schools which are then documented as 'truths' and integrated into educational, memorial, and political institutions. Because the TRC may not identify perpetrators to speak and be judged, it is up to the victims to recognize the truth that the TRC produces about the crime of residential schools.

To reframe the discussion in Foucauldian terms, the TRC is a modern juridical institution much like others in that it produces truth and uses veridiction to produce subjects who recognize it, except that truth-telling and wrong-doing have been decoupled in a substantial way. Like other judicial procedures, the TRC acknowledges a wronged victim, a perpetrator who has committed a wrong-doing, and a judge responsible for handling truth claims. Under the assumption that the IRS system was an act of wrong-doing, Indigenous people are considered to be the victims (not just former students but their entire communities), and non-Indigenous settlers are the perpetrators.; the commission is the judicial power responsible for extracting, documenting, and institutionalizing truth statements. However, settlers are not the accused party in a the modern juridical conceptualization because, while they are implicitly recognized as criminals, they are not formally accused of any wrong-doing; they lack any formal accusation to avow. This does not mean that avowal - or truth-telling, at least — is any less central to the activities of the TRC; the production of truth through an avowing subject is its raise d'être, but it is formally prohibited from producing truths through the avowal of an accused party. In contrast to the judicial models presented by Foucault, the avowing subject is the victim of a wrong-doing, not the perpetrator, and therefore 
does not necessarily risk anything through the truth-telling process; in the TRC, wrong-doing and truth-telling are not enacted by the same person as Foucault's (2014) definition of avowal suggests.

I suggest a few possibilities to explain this discrepancy, although the possibilities I offer are neither exhaustive nor mutually exclusive. One possibility is that the TRC does not actually produce truth. If the juridical process does indeed require that the one who avows must be the transgressor, as Foucault suggests, then any veridiction delivered by a victim does not constitute avowal; in this case, testimonies given by victims of IRS do not constitute avowal - they are not truth-telling in the juridical sense. But the TRC model is based on the premise that, through the documentation and institutionalization of testimonies, its function is veridiction-what Foucault calls to as 'truth-telling' and the TRC refers to as 'truth sharing.' However, just because the TRC claims to produce truth does not necessarily mean that this is the case, and truth may not be central to the truth and reconciliation process. This complicates the way we consider truth commissions. Rather than considering how truth is formulated and whose truth is told, it may be more useful to consider whether 'truth' is a meaningful idea and, if so, what makes it intelligible. Is the judicial system transforming into an institution where concepts of truth and avowal are no longer relevant or meaningful? What does this mean for a 'regime of truth' in Canadian society?

Another possibility is that the TRC, and truth commissions in general, reflect a shift in how avowal functions in juridical practice. In his concluding lecture from Wrong-Doing, Truth-Telling, Foucault (2014) briefly addresses the function of avowal in juridical systems since the nineteenth century. Modern technologies and knowledges have made it possible to conceive of a crime without reason or responsibility - crimes where the 'criminal subject' is pathologically deviant and therefore cannot avow, or the case of civil liability in which there is no criminal party. The impact of this is "so paradoxical that [it has] unsettled in part the penal machine that we now know, or at least introduced a series of impasses that, I believe, we are far from overcoming" (Foucault, 2014, p. 200). Juridical institutions have been built on the concept of avowal, but other modern institutions have since undermined the meaning of avowal. Seeing it as both necessary and meaningless, juridical procedure is confused by avowal and does not know how to integrate it into the modern system. The function of avowal in truth commissions may reflect this confusion; there may not be a criminal to avow but there is still a victim, so perhaps it is the victim who must become the avowing subject. Shifting the responsibility of avowal from the wrong-doer to the victim may be a way for the juridical system to cope with changes in technology and knowledge.

I will avoid claiming that any particular interpretation of the inconsistencies is correct because it is more interesting for both reader and writer to be left without closure; each interpretation has value depending on one's perspective. Concluding that Foucault's (2014) definition of avowal is inaccurate, or that my interpretation is incorrect, may be necessary for a positivist researcher in need of a clearly defined model, but does not have much value for one following the Foucauldian tradition. Questioning whether truth commissions actually produce truth is a more provocative question that may be useful for the political activist interested in critiquing such institutions. Suggesting that truth commissions reflect a shift in the function of avowal is perhaps most consistent with a Foucauldian approach, and leaves the door open for an array of other questions concerning truth commissions and contemporary juridical practice. After all, my analysis focuses on a very specific piece of discourse that established the framework for the TRC but does not address the larger context in which the commission operates; much has occurred in the TRC since the mandate was issued in 2006 and I have been unable to address such developments in my analysis. It is likely that exploration of the technologies and knowledges that constitute the 
wider context will provide further insights about truth commissions as a form of restorative justice and avowal in contemporary judicial process.

About the author

Jason Chalmers is a $\mathrm{PhD}$ student in the department of Sociology at the University of Alberta. He can be reached at chalmers@ualberta.ca

\section{References}

Bachmann, K. (2010). Do truth commissions make a difference? When and how truth commissions contribute to reconciliation. Review of International Affairs, 61, 71-100.

Clark, J. (2012). Reconciliation via truth? A study of South Africa's TRC. Journal of Human Rights, 11, 189-209.

Corntassel, J., \& Holder, C. (2008). Who's sorry now? Government apologies, truth commissions, and Indigenous self-determination in Australia, Canada, Guatemala, and Peru. Human Rights Review, 9, 465-89.

Foucault, M. (2014). Wrong-doing, truth-telling: the function of avowal in justice. F. Bion and B. Harcourt (Eds.). (S. Sawyer, Trans.). Chicago: University of Chicago Press.

French, B. (2009). Technologies of telling: discourse, transparency, and erasure in Guatemalan truth commission testimony. Journal of Human Rights, 8, 92-109.

Garman, A. (2006). Confession and public life in post-apartheid South Africa: a Foucauldian reading of Antjie Krog's Country of My Skull. Journal of Literary Studies, 22(3), $322-44$.

Hayner, P. (2011). Unspeakable truths: transitional justice and the challenge of truth commissions $\left(2^{\text {nd }}\right.$ ed.). New York: Routledge.

Indian Residential Schools Settlement Agreement [IRSSA] (2006). Schedule " $N$ ": Mandate for the truth and reconciliation commission. Available at: http://www.trc.ca/websites/trcinstitution/File/pdfs/SCHEDULE_N_EN.pdf

James, M. (2012). A carnival of truth? Knowledge, ignorance and the Canadian truth and reconciliation commission. International Journal of Transitional Justice, 6(2), 182-204.

Jeganathan, P. (2010). In the ruins of truth: the work of melancholia and acts of memory. InterAsia Cultural Studies, 11(1), 6-20. 


\section{CGJSC / RCESSC}

Kashyap, R. (2009). Narrative and truth: a feminist critique of the South African truth and reconciliation commission. Contemporary Justice Review, 12(4), 449-687.

Macias, T. (2013). 'Tortured bodies': the biopolitics of torture and truth in Chile. International Journal of Human Rights, 17(1), 113-32.

May, R. (2013). 'Truth' and truth commissions in Latin America. Investigación y Desarrollo, 21(2), 494-512.

Mbembe, A. (2001). On the postcolony. Berkeley: University of California Press.

McCalpin, J. (2013). Written into amnesia? The truth and reconciliation commission of Grenada. Social and Economic Studies, 62(3/4), 113-40.

Regan, P. (2010). Unsettling the settler within: Indian Residential Schools, truth telling, and reconciliation in Canada. Vancouver: UBC Press.

Roosa, J. (2008). How does a truth commission find out what the truth is? The case of East Timor's CAVR. Pacific Affairs, 80(4), 569-80.

Stasiulis, D., \& Yuval-Davis, N. (1995). Introduction: Beyond dichotomies - gender, race, ethnicity and class in settler societies. In D. Stasiulis \& N. Yuval-Davis (Eds.), Unsettling settler societies: articulations of gender, race, ethnicity and class (pp. 1-38). London: Sage Publications.

Stasiulis, D., \& Jhappan, R. (1995). The fractious politics of a settler society: Canada. In D. Stasiulis \& N. Yuval-Davis (Eds.), Unsettling settler societies: articulations of gender, race, ethnicity and class (pp. 95-131). London: Sage Publications.

Twose, G. (2010). Going beyond truth in reconciliation. Review of International Affairs, 61, 41-70. 